\title{
EFEITOS ADVERSOS DA RADIOTERAPIA DE CABEÇA E PESCOÇO.
}

Liana Machado DALPRÁ; Felipe Andretta COPELLI; Carolyne Pazzetto TELLES; Bruna Jussara LOCKS; Maria Helena TOMMASI.

A radioterapia tem como filosofia a irradiação de células tumorais e preservação dos tecidos normais incluídos no campo de irradiação. $O$ agente terapêutico nesse tratamento é a radiação ionizante, que pode agir de forma direta ou indireta sobre a molécula de DNA. Apesar de a radiação favorecer boa resposta frente às neoplasias malignas, ela pode desencadear também alterações no tecido normal. As reações adversas irão depender do volume e do local irradiado, da dose total, do fracionamento, da idade, das condições clínicas e da resposta individual do paciente. As reações agudas ocorrem durante o curso do tratamento e são em geral reversíveis. Já as reações crônicas ou tardias são em geral irreversíveis e resultam em incapacidade permanente e piora da qualidade de vida do paciente. As alterações agudas e tardias são: xerostomia, alterações da flora bacteriana bucal, alterações do paladar, trismo muscular, cárie de radiação, candidíase e osteorradionecrose. Tendo em vista o número de lesões e a gravidade das mesmas, pode-se afirmar que a odontologia constitui-se numa especialidade essencial nos aspectos preventivo, curativo e reabilitador das seqüelas oriundas do tratamento cirúrgico e radioterápico dos tumores de cabeça e pescoço. 